\title{
Aldonate Coupling, A Simple Procedure for the Preparation of Carbohydrate-Protein Conjugates for Studies of Carbohydrate- Binding Proteins ${ }^{1}$
}

\author{
JÖRGEN LÖNNGREN, ${ }^{2,3}$ IRWIN J. GOLDSTEIN,2 \\ AND JOHN E. NIEDERHUBER ${ }^{4,5}$

\begin{abstract}
Departments of Biological Chemistry, Microbiology and Surgery, The University of Michigan, Ann Arbor, Michigan 48109
\end{abstract}

Received January 12, 1976

\begin{abstract}
Aldonate coupling, a new, high-yield method for conjugation of reducing oligosaccharides to proteins is described. It involves oxidation of the oligosaccharides to their corresponding aldonic acids followed by coupling to amino functions of proteins by activation of carboxyl groups with a water-soluble carbodiimide derivative. The immunochemical properties of some of these synthetic glycoproteins were assessed using several plant agglutinins (lectins) as well as antibodies raised to the conjugates. The scope and limitation of the method are discussed.
\end{abstract}

The preparation of conjugates from carbohydrates and proteins has received considerable attention for nearly half a century. The classical method for their synthesis involves preparation of $p$-aminophenyl or $p$-aminobenzyl glycosides of the sugar followed by coupling to the protein via a diazotization reaction (1-3). The yield in the conjugation can be considerably improved by conversion of the amino function to an isothiocyanate derivative (4). Further methods involve preparation of the 1-( $m$-aminophenyl)-flavazole of the sugar followed by diazotization (5) and use of cyanuric trichloride as the coupling agent (6). The reduction by borohydride of a Schiff base formed between a reducing

${ }^{1}$ Supported in part by Damon Runyon DRG 1260 , Michigan Kidney Foundation, National Institutes of Health Grant R01-AI-12153-01, U.S. Public Health Service Grant AM 10171 and American Cancer Society Institutional Grant IN-40M.

${ }^{2}$ Department of Biological Chemistry.

${ }^{3}$ On leave from University of Stockholm, Arrhenius Laboratory, Department of Organic Chemistry, S-10405 Stockholm, Sweden.

4 Departments of Microbiology and Surgery.

${ }^{5}$ Recipient of U. S. Public Health Service Research Career Development Award. sugar and proteins has also been used as a coupling reaction (7). Arakatsu et al. oxidized reducing oligosaccharides to aldonic acids and coupled these to bovine serum albumin (BSA) ${ }^{6}$ using the mixed anhydride method (8). The same approach has been applied to the preparation of conjugates of oligosaccharides from human milk and polylysine (9). Recently, Lemieux and co-workers linked a number of 8-carboxyoctyl glycosides (related to human bloodgroup substances) to BSA by conversion of the corresponding hydrazides to acyl azides via diazotization (10).

The synthetic glycoproteins prepared by the above procedures have been widely used to raise antibodies to defined structural moieties in polysaccharides $(8,10-12)$ and to study the specificity and cross reactivity of antibody-combining sites $(8,12-$ 14). Carbohydrate-protein conjugates

${ }^{6}$ Abbreviations used: BSA, bovine serum albumin; EDC, 1-ethyl-3-(dimethylaminopropyl)-carbodiimide hydrochloride; con $\mathrm{A}$, concanavalin $\mathrm{A}$; $\mathrm{RCA}_{1}$, lectin from Ricinus communis; HEPES, 4-(2hydroxyethyl-1-piperazineethanesulfonic acid; D.S., degrees of substitution, number of sugar residues per molecule of bovine serum albumin; SDS, sodium dodecyl sulfate; $T$ cell, thymus-derived lymphocyte. 
have also been used as model glycoproteins in studies of lectin carbohydratebinding specificities $(15,16)$. However, several of these conjugates suffer from the disadvantage inherent in the particular kind of carbohydrate-protein linkage present in the conjugate. Notably, aromatic structures appear to give rise to nonspecific interactions in certain lectin systems (15) as well as undesirable antibody specificity toward the conjugate linkage region when these conjugates are used as antigens (12).

In connection with studies of the $\alpha$-Dgalactopyranosyl-binding lectin isolated from the seeds of Bandeiraea simplicifolia it was found that melibionic acid could be conjugated in high yield to aminoethyl Bio-Gel using a water-soluble carbodiimide (1-ethyl-3-(dimethylaminopropyl)carbodiimide hydrochloride, EDC) (17). This gel was used in affinity columns to isolate the pure lectin. It seemed reasonable to assume that an analogous reaction could be employed to link various oligosaccharides, as their aldonic acids, to proteins. Experiments aimed at synthesis of these conjugates and evaluation of their immunochemical properties are reported in the present communication.

\section{EXPERIMENTAL PROCEDURES}

Materials. Bovine serum albumin was purchased from Miles Laboratories, Kankakee, Ill.; ovalbumin from Sigma Chemical Company, St. Louis, Mo.; concanavalin A from Calbiochem, La Jolla, Calif;; and 1-ethyl-3-(3-dimethylaminopropyl)-carbodiimide hydrochloride from the Pierce Chemical Company, Rockford, Ill. The B. simplicifolia lectin was isolated as described (17) while Ricinus communis lectin $\left(\mathrm{RCA}_{1}\right)$ was the kind gift of Dr. Marilyn E. Etzler, University of California, Davis, Calif. The carbohydrates used were obtained from Pfanstiehl Laboratories, Waukegan, Ill., or were available in this laboratory.

Analytical methods. Hexose concentrations were determined by the phenol-sulfuric acid assay (18) against blanks of appropriate protein using standards of suitable methyl glycosides. Protein concentrations were determined by the microbiuret assay using BSA as standard (19). Precipitates from precipitation and inhibition studies were digested, and nitrogen was determined by a modification (17) of the ninhydrin procedure of Rosen (20). Electrophoresis on polyacrylamide gels $(7.5 \%)$ was per- formed at $\mathrm{pH} 4.3$ in $\beta$-alanine-acetic acid buffer (21), and sodium dodecyl sulfate electrophoresis in polyacrylamide gels was performed essentially as earlier described (22). Protein staining was performed with Coomassie brilliant blue.

Immunochemical methods. For precipitation and inhibition studies involving lectins, essentially the same procedures as described previously (17) were used except that all reactions were performed in a total volume of $500 \mu \mathrm{l}$, and all components were dissolved in $0.01 \mathrm{M}$ sodium phosphate-buffered saline $(0.15 \mathrm{M})$ of $\mathrm{pH}$ 7.2. Precipitation reactions were incubated for $48 \mathrm{~h}$ at room temperature (except for tempcrature-dependence studies). In volume-dependence studies total volumes of $0.3,0.5,1.0,1.5$, and $2.0 \mathrm{ml}$ were used. The digestion of the precipitates was performed as already described (23).

For immunization experiments a group of three adult New Zealand white rabbits was challenged with the melibionate-BSA conjugate containing 34 mol of sugar per mol of BSA. The antigen at a concentration of $1 \mathrm{mg} / \mathrm{ml}$ was homogenized in Freund's complete adjuvant (Difco Laboratorics, Detroit, Mich.) using a Virtis microblender. This emulsion was injected into each of four foot pads $(0.1$ $\mathrm{ml})$ and subcutaneously in the back $(0.1 \mathrm{ml})$ for 3 successive weeks. Blood was drawn from the marginal vein of the ears at weekly intervals beginning 1 week after the last injection. The sera obtained, after separation of the blood clot, was stored frozen without addition of preservative. The methods for precipitation reactions and inhibition assays were essentially as outlined by Kabat (24). All assays were performed using 100 or $200 \mu \mathrm{l}$ of serum (pool from three bleedings) in a total volume of $500 \mu 1$. Precipitation reactions were allowed to proceed for 1 week at $0^{\circ} \mathrm{C}$. Ouchterlony plates were prepared as described (25). None of the rabbits used in this study showed a significant preimmunization titer against immunizing antigen.

Synthetic methods. Aldonic acids (isolated as their potassium salts) were prepared by the procedure of Moore and Link (26).

In a typical coupling experiment, polassium melibionate $(1.3 \mathrm{~g})$ was added to a rapidly stirred solution of BSA (400 mg in $4.0 \mathrm{ml}$ of water). The $\mathrm{pH}$ was adjusted to 4.75 using $1.0 \mathrm{~m}$ hydrochloric acid. A solution of EDC (620 mg in $1.0 \mathrm{ml}$ of water) was added dropwise over $30 \mathrm{~min}$, at room temperature, the $\mathrm{pH}$ being maintained at 4.75 by addition of $0.5 \mathrm{M}$ hydrochloric acid. After approximately $40 \mathrm{~min}$ the reaction ceased to consume acid. The solution was left for an additional $6 \mathrm{~h}$, during which time the $\mathrm{pH}$ gradually dropped to approximately 3.5. Addition of sodium acetate buffer $(5 \mathrm{ml}, 1 \mathrm{M}, \mathrm{pH} 5.5)$ served to quench the reaction, and the modified protein was dialyzed exhaustively against distilled water. Additional experiments were carried out varying the 
proportions of sugar to protein. The results of the coupling experiments are summarized in Table I.

Melibionic acid was conjugated to ovalbumin using the same procedure as used for BSA.

Melibionic acid was also conjugated to con $A$ in a solution $(25 \mathrm{ml})$ containing $7.5 \mathrm{mg} / \mathrm{ml}$ of protein in 1 M sodium chloride- $0.1 \mathrm{M}$ methyl $\alpha$-D-mannopyranoside. Potassium melibionate $(975 \mathrm{mg})$ was added and the $\mathrm{pH}$ was adjusted to 4.75 . EDC solution $(465 \mathrm{mg}$ in $2.0 \mathrm{ml}$ of water) was added over $15 \mathrm{~min}$ with $\mathrm{pH}$ control. After $\mathbf{3 0}$ min the reaction was quenched by addition of an excess of acetate buffer, and the solution was dialyzed exhaustively against $0.15 \mathrm{M}$ sodium chloride. The yield of soluble protein was $80 \%$.

Culture methods. Several strains of mice were used to test the mitogenic properties of melibionatecon A: $\mathrm{B} 10 . \mathrm{Br}\left(I I-2^{k}\right)$, $\mathrm{B} 10 . \mathrm{K}\left(H-2^{k}\right), \quad \mathrm{B} 10 . \mathrm{A}(3 \mathrm{R})-$ $\left(H-2^{i 3}\right)$, Balb/c $\left(H-2^{d}\right)$, and athymic, homozygous nude Balb/c ( $n u / n u)$ mice. The mice were maintained in Dr. Niederhuber's colony at The University of Michigan, and in each experiment were matched for age and sex.

Spleen cells were dispersed by teasing in serumfree RPMI 1640 medium (Microbiological Associates, Bethesda, Md.) supplemented with $3 \mathrm{ml}$ of HEPES $(1 \mathrm{~m})$ and $50 \mu \mathrm{g} / \mathrm{ml}$ of gentamycin per 100 $\mathrm{ml}$. Quadruplicate cultures of $5 \times 10^{5}$ viable lymphoid cells per well were incubated in multiwell Linbro plates (Linbro Chemical Co., New Haven, Conn.) for $72 \mathrm{~h}$. Cultures were stimulated with a dose range of con A or melibionate-con A. Final volume in each well was $0.3 \mathrm{ml}$, and cullure plates were incubated at $37^{\circ} \mathrm{C}$ in a humidified atmosphere of $5 \% \mathrm{CO}_{2}$.

During the last $18 \mathrm{~h}$ of culture, $0.2 \mu \mathrm{Ci}$ of [ $\left.{ }^{3} \mathrm{H}\right]$ thymidine $(2 \mathrm{Ci} / \mathrm{mmol})$ was present in the cultures. Cultures were harvested and assayed for the incorporation of $\left[{ }^{3} \mathrm{H}\right]$ thymidine into DNA using a multiple sample harvester (Otto Hiller Co., Madison, Wis.). The acid-precipitable DNA was collected on glass-fiber filters and counted in a liquid scintillation counter using a toluene-based scintillation fluid.

Thymus-derived lymphocytes were prepared from whole spleen using nylon wool (LP-1 Leuko-pak leukocyte filter, Fenwal Laboratories, Morton Grove, Ill.), as described by Julius et al. (27). Such cells are 80-90\% Thy-1 positive.

\section{RESULTS AND DISCUSSION}

\section{The Coupling Reaction}

The aldonic acids (as potassium salts) of reducing sugars used in this study were prepared by oxidation with alkaline iodine (26). The yield in this reaction is essentially quantitative and the preparation does not require further purification.

The coupling reaction involves activation of the carboxyl group of the sugar derivative by reaction with a water-soluble carbodiimide (EDC) to give an $O$-acylisourea $(28)$. The latter reacts with accessible nucleophiles in the protein, e.g., $\epsilon-$ amino groups of lysyl residues, forming amide linkages (peptide bonds). In the procedure used, an EDC solution is added over $30 \mathrm{~min}$ to a rapidly stirred water solution of the protein and the aldonic acid. During this time the acidity of the reaction mixture is carefully controlled by addition

TABLE I

Properties and Yields of Aldonate-Bovine Serum Albumin Conjugates

\begin{tabular}{lcccccc}
\hline Aldobionic acid & $\begin{array}{c}\text { Molar ratio of } \\
\text { aldonic acid } \\
\text { to protein in } \\
\text { reaction mix- } \\
\text { ture }\end{array}$ & $\begin{array}{c}\text { Molar ratio } \\
\text { of aldonic } \\
\text { acid to ly- } \\
\text { syl resi- } \\
\text { dues in re- } \\
\text { action mix- } \\
\text { ture }\end{array}$ & $\begin{array}{c}\text { Molar ratio } \\
\text { of sugar to } \\
\text { protein in } \\
\text { product } \\
(D . S .)\end{array}$ & Yield $^{a}(\%)$ & Yield $^{a}(\%)$ & Yield $^{c}(\%)$ \\
Melibionic acid & 1300 & 22 & 32 & 93 & 54 & 2.5 \\
Melibionic acid & 540 & 9 & 34 & 104 & 58 & 6.4 \\
Melibionic acid & 300 & 5 & 22 & 83 & 37 & 7.4 \\
Melibionic acid & 120 & 2 & 12 & 83 & 20 & 10 \\
Melibionic acid & 60 & 1 & 7 & 88 & 12 & 12 \\
Gentiobionic acid & 540 & 9 & 48 & 105 & 81 & 9 \\
Lactobionic acid & 540 & 9 & 37 & 105 & 63 & 7 \\
Maltobionic acid & 540 & 9 & 45 & 91 & 76 & 8.4 \\
Maltotrionic acid & 540 & 9 & 33 & 92 & 56 & 6.2 \\
\hline
\end{tabular}

a Yield of recovered protein according to microbiuret assay.

- Yield in coupling reaction assuming 59 lysyl residues per BSA molecule (29).

${ }^{c}$ Based upon amount of starting sugar present in the reaction solution. 
of acid. After standing for $6 \mathrm{~h}$ at room temperature, the reaction is quenched by addition of an excess of acetate ions, and the conjugate is dialyzed free of reagents. The carbohydrate content of the conjugates was determined by the phenol-sulfuric acid assay (18). The yields and reaction conditions used for the synthesis of several conjugates of BSA are presented in Table I. As seen in the table, the highest degrees of substitution (D.S., number of sugar residues per BSA molecule) was obtained when the molar ratio of sugar to BSA in the reaction mixture was $\geq 500$. The yields obtained compare well with the best procedures described. The isothiocyanate coupling procedure (4) gives a maximum $D . S$. of 54 whereas the diazotization procedure of Lemieux and co-workers (10) gives D.S. of about 35, both to BSA. Furthermore, it is apparent that the D.S. could be readily controlled by varying the molar proportions of sugar to protein in the reaction mixture. All the BSA conjugates appeared as multiple bands on polyacrylamide electrophoresis at $\mathrm{pH}$ 4.3. This demonstrates that the conjugate preparations comprise mixtures of populations of BSA molecules bearing different numbers of sugar residues on the amino functions. In contrast, the conjugates appeared as a single band upon SDS-gel electrophoresis, showing that no appreciable aggregation had occurred.

The aldonate coupling reaction was also used to covalently link melibionic acid to ovalbumin and to concanavalin A (see below) and it is readily apparent that the method can be used for the coupling of virtually any aldonic acid prepared from natural and synthetic oligosaccharides to various protein carriers. However, an obvious limitation of the procedure involves loss of the reducing sugar residue which becomes the conjugation "arm." It should also be possible to link other carbohydrates containing carboxyl groups, e.g., uronic acid containing sugars or glycosides of aglycones containing carboxyl groups, in an analogous fashion.

\section{Evaluation of the Immunochemical Prop- erties of the Conjugates Using Lectins}

The interaction of the aldonate-BSA conjugates with lectins was investigated. Of the different systems studied the properties of the melibionate-BSA conjugates in their interaction with the $\alpha$-D-galactopyranosyl-binding lectin from $B$. simplicifolia (17) was investigated most thoroughly.

Figure 1 presents the quantitative precipitation curves obtained when the $B$. simplicifolia lectin interacted with melibionate-BSA conjugates of D.S. 34, 22, and 7 . About $80-90 \%$ of the added protein could be precipitated by the conjugates of $D . S .34$ and 22 . It is apparent from the early stages of the precipitin curves that the order of reactivity of the conjugates is related directly to the number of melibionate units present on the protein. The solubility of the lectin melibionate-BSA (D.S. 34) precipitate was determined by performing the precipitin reaction at a point in the "equivalence zone" in five different volumes ranging from 0.3 to $2.0 \mathrm{ml}$. Virtually the same amount of precipitate was formed in all instances. The influence of temperature on the reaction was assessed by incubation of the precipitating system at 37,23 , and $0^{\circ} \mathrm{C}$. No significant difference was observed between the 23 and $0^{\circ} \mathrm{C}$ experiments but at $37^{\circ} \mathrm{C}$ only about $85 \%$ of the amount of precipitate formed. These results closely parallel those obtained from similar investigations (17) on the $B$. simplicifolia lectin-guaran system and indicate that the lectin-conjugate precipitate has a low solubility. Several glycosides and dissacharides were tested for their

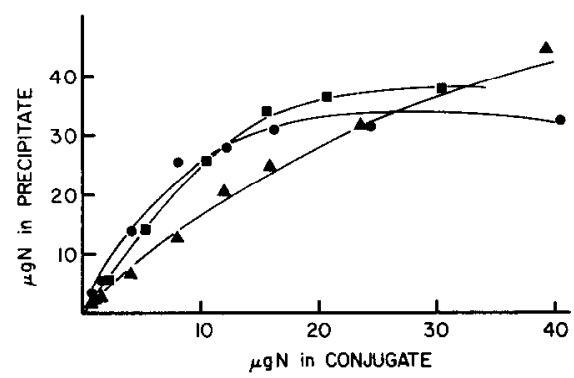

FIG. 1. Comparison of precipitating power of melibionate-BSA conjugates containing varying amounts of melibionate residues; ( $\boldsymbol{\Delta}), 7$ melibionate residues/mol of BSA; ( $\square$ ), 22 melibionate residues/ mol of BSA; () , 34 melibionate residues/mol of BSA. B. simplicifolia lectin, $22.8 \mu \mathrm{g}$ of nitrogen per tube. 
ability to inhibit the precipitation reaction. The results are summarized in Table II. The concentrations of sugars required for $50 \%$ inhibition of the $B$. simplicifolia lectin-melibionate-BSA system are somewhat lower than the corresponding values for the same lectin interacting with guaran (17). Nevertheless, the ratios of inhibitor concentrations are comparable in both systems. The results indicate that the interaction between the lectin and the BSA conjugate, although highly specific, is somewhat weaker than in the guaran system. However, the interaction appears to involve solely the carbohydrate-binding site of the lectin; no hydrophobic interactions appear to be involved as is true for carbohydrate-protein conjugates containing azophenyl linkages (15). This is apparent from the fact that the precipitin reaction was completely inhibited by several sugars. Furthermore, a lactobionate-BSA conjugate failed to precipitate the $B$. simplicifolia lectin; polysaccharides and glycoproteins containing terminal $\beta$-D-galactopyranosyl groups also fail to precipitate this agglutinin (17).

The maltobionate-BSA conjugate ( $D . S$. 45) was investigated next. Quantitative precipitation studies (Fig. 2) with concanavalin $\mathrm{A}$ (con $\mathrm{A}$ ) demonstrate that only about $50 \%$ of the total added protein was precipitated in the "equivalence zone." This indicates a relatively weak conjugate-lectin interaction. Inasmuch as $\alpha$ D-glycopyranosyl groups are among the structures most complementary to the binding site of con A (30), these results

\section{TABLE II}

HAPTEN INHIBITION OF THE B. simplicifolia LECTINMelibionate-BSA System

\begin{tabular}{lc}
\hline \multicolumn{1}{c}{ Sugar } & $\begin{array}{c}\text { Concentration } \\
\text { for } 50 \% \text { inhibi- } \\
\text { tion (mM) }\end{array}$ \\
\hline Methyl $\alpha$-D-galactopyranoside & 0.48 \\
Melibiitol & 0.58 \\
Melibiose & 0.60 \\
D-Galactose & 1.6 \\
Methyl $\beta$-D-galactopyranoside & 3.1 \\
Lactose & $15 \%$ inhibition \\
Methyl $\alpha$-D-mannopyranoside & $0 \%$ inhibition at \\
& $20 \mathrm{~mm}$ \\
\hline
\end{tabular}

appear somewhat surprising. The weak lectin-conjugate interaction was confirmed by hapten-inhibition studies. The concentrations of several sugars necessary to produce $50 \%$ inhibition of the precipitation reaction are given in Table III. The values obtained compare with those obtained in studies of the con A-levan system which shows a considerably weaker interaction than, for example, con $\mathrm{A}$ and dextrans (31). As in the B. simplicifolia lectin-melibionate-BSA system, complete inhibition was achieved indicating that nonspecific binding does not occur. As expected a gentiobionate-BSA conjugate failed to precipitate with con $A$; it is known that $\beta$-D-glucopyranosyl groups bind only weakly if at all to the lectin.

The maltotrionate-BSA conjugate contained 33 residues of maltotrionate groups per mole of protein. As a precipitant of con $\mathrm{A}$, the maltotrionate-BSA conjugate containing two intact $\alpha$-D-glucopyranosyl

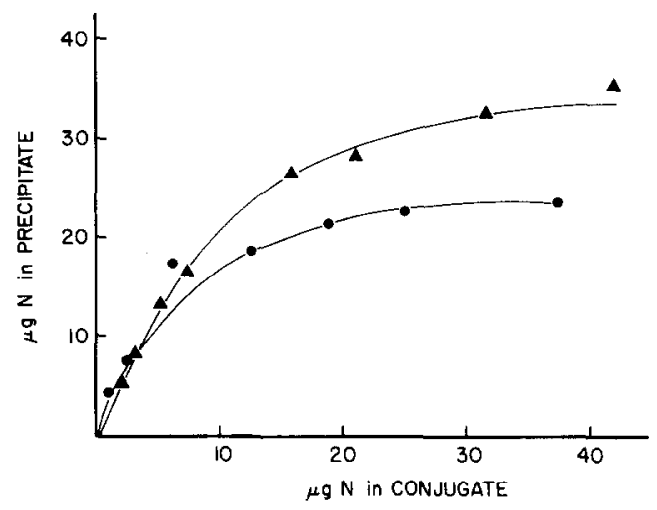

FIG. 2. Quantitative precipitin curves of maltobionate-BSA conjugate (O) and maltotrionate-BSA conjugate (A) with con A. Con A, 19.5 and $16.3 \mu \mathrm{g}$ of nitrogen per tube, respectively.

TABLE III

Hapten Inhibition of the con A-MaltobionateBSA System

\begin{tabular}{lc}
\hline \multicolumn{1}{c}{ Sugar } & $\begin{array}{c}\text { Concentration } \\
\text { for 50\% inhibi- } \\
\text { tion (mM) }\end{array}$ \\
\hline Methyl $\alpha$-D-mannopyranoside & 0.20 \\
Methyl $\alpha$-D-glucopyranoside & 0.85 \\
Maltose & 2.6 \\
Methyl $\beta$-D-glucopyranoside & 21.0 \\
D-Galactose & $13 \%$ inhibition \\
& at 200 mM \\
\hline
\end{tabular}


units is superior to the maltobionate-BSA conjugate containing but a single $\alpha$-D-glucopyranosyl group (Fig. 2). Under the conditions employed, the maltotrionate conjugates required $0.27 \mathrm{~mm}$ methyl $\alpha$-D-mannopyranoside for $50 \%$ inhibition.

The interactions between the Ricinus communis lectin $\left(\mathrm{RCA}_{\mathrm{I}}\right)$ and the melibionate-BSA (D.S. 34) and lactobionate-BSA (D.S. 37) conjugates were investigated. The quantitative precipitation curves are shown in Fig. 3. This lectin specifically binds D-galactopyranosyl groups; $\beta$-glycosides are bound somewhat more strongly than the $\alpha$-anomers (32). The amounts of lectin-conjugate complex precipitated by the two conjugates reflect this specificity inasmuch as the lactobionate conjugate is considerably more effective than the melibionate conjugate.

The results discussed above indicate that BSA conjugates of aldonic acids are suitable agents for studies of lectins, e.g., in evaluation of their carbohydrate-binding specificity.

\section{Preparation and Investigation of a Carbo- hydrate-con A Conjugate}

Melibionic acid was linked to con A using the same procedure as for the synthesis of the BSA conjugates, although a shorter reaction time was used and the lectin was "protected" by the presence of methyl $\alpha$-D-mannopyranoside. The melibionic-con A conjugate contained approximately six sugar residues per mole of protein. This conjugate showed approximately $50 \%$ of the activity of native con A

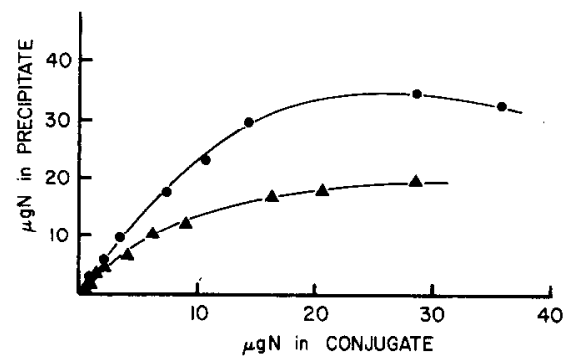

FIG. 3. Quantitative precipitin curves of melibionate-BSA conjugate $(\boldsymbol{\Delta})$ and lactobionate-BSA conjugate (O) with Ricinus communis $\left(\mathrm{RCA}_{1}\right)$ lectin. Ricinus communis lectin, $19.5 \mu \mathrm{g}$ of nitrogen per tube. when assayed by the quantitative precipitation reaction against dextran B- 1355 . The $B$. simplicifolia lectin reacted with the melibionate-con A conjugate generating a typical precipitin curve (Fig. 4). In this experiment the incubation solution contained methyl $\alpha$-D-mannopyranoside in order to abolish the reactivity of melibionate-con A against $B$. simplicifolia lectin since the latter is a glycoprotein containing a carbohydrate moiety with which con A reacts (17).

The con A conjugate was also tested for its capacity to stimulate mouse spleen cells and nylon wool-purified splenic T lymphocytes, as measured by incorporation of $\left[{ }^{3} \mathrm{H}\right]$ thymidine into DNA. The dose-response curve is given in Fig. 5 together with that obtained from native con $\mathrm{A}$ under the same conditions. The curve obtained for the con A conjugate resembles those reported for acetyl- and succinyl-con A $(33,34)$.

The melibionate-con A gave similar stimulation with nylon wool-purified splenic $\mathrm{T}$ cells but no stimulation was obtained using splenic B cells from congenitally athymic Balb/c (nu/nu) mice. The con A conjugate, therefore, retained the properties of a T-cell mitogen. The mitogenic activity could be inhibited by methyl $\alpha$-D-mannopyranoside at the same concentration as for native con $\mathrm{A}$.

The experiment reported above justifies the conclusion that carbohydrates can be conjugated to certain biologically active

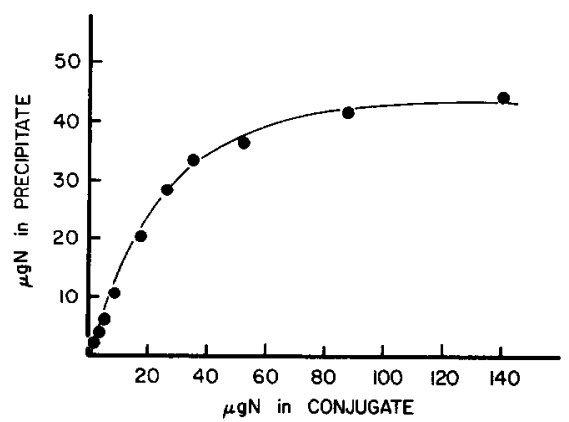

FIG. 4. Quantitative precipitin curve of melibionate-con A conjugate with $B$ simplicifolia lectin in the presence of $50 \mathrm{~mm}$ methyl $\alpha$-D-mannopyranoside. $B$. simplicifolia lectin, $26.4 \mu \mathrm{g}$ of nitrogen per tube. 


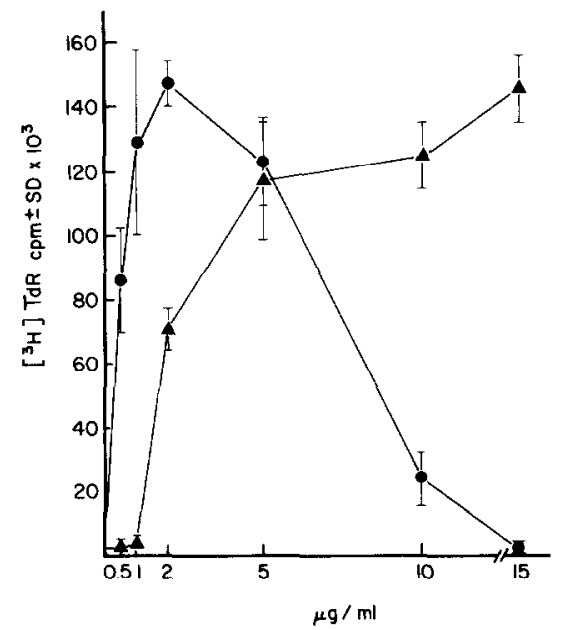

Fig. 5. Dose-response curves obtained on stimulation of mouse spleen cells with con $A(-)$ and melibionate-con A (A).

proteins by the present method with retention of activity.

\section{Evaluation of Immunochemical Properties of the Conjugates Using Hapten-Specific Antibodies}

The melibionate-BSA conjugate (D.S. 34) was used as antigen in immunization experiments with rabbits. A set of three rabbits was sensitized with the antigen in Freund's complete adjuvant. For evaluation of the hapten-specific response a second conjugate, namely, melbionate-ovalbumin $(D . S . \sim 5)$, was synthesized. This conjugate contains the homologous hapten linked to a heterologous carrier, thus abolishing any precipitation of antibodies against the BSA carrier in precipitation reactions. Two-dimensional immunodiffusion of various conjugates against an antiserum raised against melibionate-BSA is shown in Fig. 6. The expected spur formation between BSA and melibionate-BSA as well as between the latter and melibionate-ovalbumin is clearly discernible. The quantitative precipitation curves obtained from the individually pooled antisera of three different rabbits from three successive bleedings are presented in Fig. 7. The antibody titers are quite different in the three animals. Nevertheless, it is apparent that the conjugates give rise to haptenspecific antibodies and that the titers com- pare well with those obtained employing other types of conjugates.

Kabat and colleagues have made a careful evaluation of the hapten-specific antibody response in rabbits to closely related antigens (8). In their study, isomaltonic and isomaltotrionic acid conjugates of BSA (D.S. approximately 10) were used to assess the size of the antibody-combining site. The isomaltonate-BSA conjugate gave antibodies which were incapable of

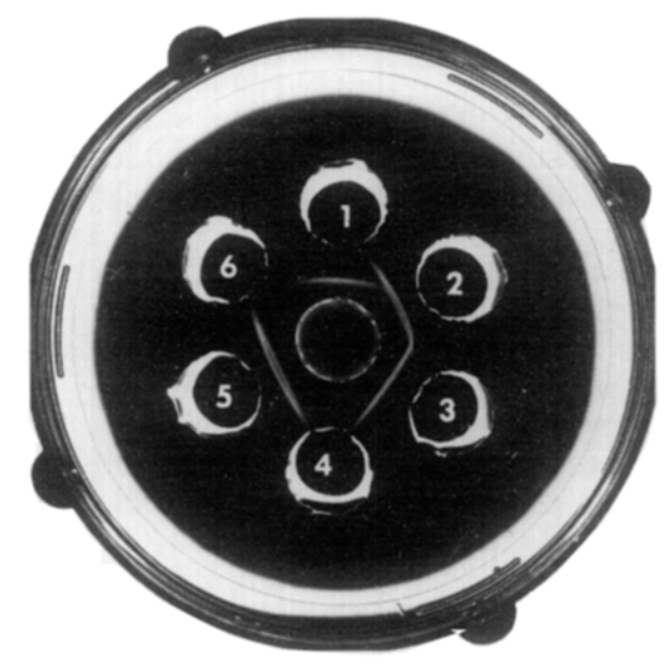

Fig. 6. Ouchterlony double diffusion in agar. Center well, melibionate-BSA antiserum; well 1, melibionate-ovalbumin conjugate; well 2 , melibionate-BSA conjugate; well 3 , BSA; well 4, saline control; well 5, melibionate-BSA conjugate; well 6, gluconate-ovalbumin conjugate. All samples were 0.5 $\mathrm{mg} / \mathrm{ml}$ in saline.

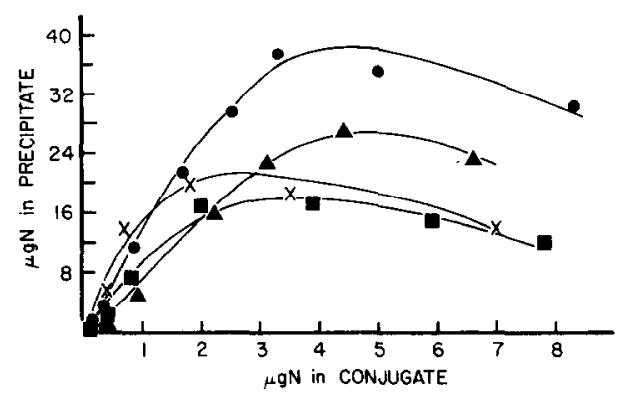

FIG. 7. Quantitative precipitin curves of melibionate-ovalbumin conjugate with melibionateBSA antiserum. (๑), Rabbit $1,100 \mu$ l of serum; ( $\square$ ), rabbit $2,100 \mu \mathrm{l}$ of serum; ( $\boldsymbol{\Delta})$, rabbit $3,200 \mu \mathrm{l}$ of serum. ( $\times$ ), Quantitative precipitin curve of gluconate-ovalbumin with melibionate-BSA antiserum $(200 \mu \mathrm{l})$ from rabbit 1 . 
precipitating dextrans. Our results confirm this finding inasmuch as none of the antisera raised to melibionate-BSA conjugate was capable of precipitating guaran or blood-group B substance. These results show that a single glycosyl residue does not generate antibodies capable of precipitating a heterologous substance containing this residue as the only structural feature in common with the immunizing antigen. This is in accord with the general view which requires that the antibodycombining site be complementary to at least two sugar units in order to form precipitates with a heterologous polysaccharide $(8,35)$. The quantitative hapten inhibition studies presented in Fig. 8 lend further support to this view. It is apparent that potassium melibionate is by far the most potent inhibitor. Despite the fact that methyl $\alpha$-D-galactopyranoside and melibiose both contain nonreducing $\alpha$-D-galactopyranosyl groups, an approximately 500 times higher concentration of these substances was required to produce $50 \%$ inhibition of the precipitation system. A $\beta$ glycoside, e.g., methyl $\beta$-D-galactopyranoside, is essentially noninhibitory, demonstrating the importance of the anomeric center. Melibiose parallels methyl $\alpha$-D-galactopyranoside as an inhibitor. Potassium gentiobionate is comparable to methyl $\alpha$ D-galactopyranoside, and this together with the fact that potassium melibionate is so potent an inhibitor justifies the conclusion that the gluconate "arm" plays an

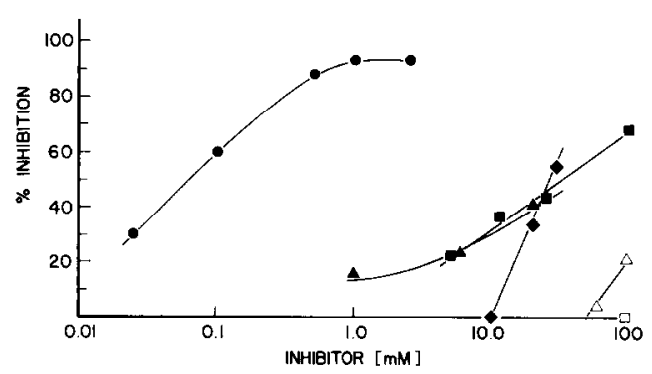

FIG. 8. Inhibition of melibionate-BSA antiserum (100 $\mu$ l from rabbit 1) precipitation of melibionate-ovalbumin conjugate by low molecular weight sugars. ( $)$, Potassium melibionate; ( $\mathbf{\Delta})$, melibiose; (Ш), methyl $\alpha$-D-galactopyranoside; ( ), potassium gentiobionate; $(\Delta)$, methyl $\beta$-D-galactopyranoside; ( $\square$, methyl $\alpha$-D-glucopyranoside. important role in the binding specificity of the antibody-combining site. Indeed, antiserum from one rabbit precipitated a gluconate-ovalbumin conjugate as illustrated in Figs. 6 and 7. This could, however, be due to a population of antibodies directed exclusively to the gluconate residue and not to antibodies complementary to melibionate. Thus, the majority of antibodies raised by the melibionate-BSA conjugate have a combining site complementary to the galactosyl residue plus the gluconate moiety, i.e., the melibionate group. The relative importance of the glyconate moiety can be expected to decrease in conjugates prepared from larger oligosaccharides.

These studies indicate that aldonic acidBSA conjugates prepared by the aldonate coupling technique are potent immunogens. Most of the antibodies raised to an aldobionate conjugate appears to include the glyconate "arm" in the combining site which tends to limit the utility of the method for preparation of antibodies against a specific nonreducing monosaccharide structure. However, the aldonate coupling method should be of interest in the preparation of antibodies to larger oligosaccharides. Furthermore, oligosaccharide conjugates can be prepared and used in evaluating the cross reactivity and carbohydrate specificity of antisera prepared by immunization with "natural" carbohydrate antigens.

\section{ACKNOWLEDGMENTS}

The authors are indebted to Dr. Marilynn E. Etzler, University of California, for a gift of ricin and to Miss Paula Kane for skillful technical assistance. A travel grant to one of us (Jörgen Lönngren) from the Sweden-American Foundation is gratefully acknowledged.

\section{REFERENCES}

1. Goebel, W. F., and Avery, O. T. (1929) J. Exp. Med. 50, 521-531.

2. Avery, O. T., ANd Goebel, W. F. (1929) J. Exp. Med. 50, 533-550.

3. Goebel, W. F. (1936) J. Exp. Med. 64, 29-38.

4. McBroom, C. R., Samanen, C. H., and GoldSTEIN, I. J. (1972) Methods Enzymol. 28B, 212219.

5. Himmelspach, K., Westphal, O., and TeichMAN, B. (1971) Eur. J.Immunol. 1, 106-112. 
6. Fiedler, R. J., Bishop, C. T., Grappel, S. F., AND BlaNK, F. (1970) J. Immunol. 105, 265267.

7. Gray, G. R. (1974) Arch. Biochem. Biophys. 163, 426-428.

8. Arakatsu, Y., Ashwell, G., and Kabat, E. A. (1966) J. Immunol. 97, 858-866.

9. Zorf, D. A., And Ginsbung, V. (1975) Arch. Biochem. Biophys. 167, 345-350.

10. Lemieux, R. U., Bundle, D. R., ANd Baker, D. A. (1975) J. Amer. Chem. Soc. 97, 4076-4083.

11. Lüderitz, O., Staub, A. M., and Westphal, $O$. (1966) Bacteriol. Rev. 30, 192-255.

12. Martineau, R. S., Allen, P. Z., Goldstein, I. J., AND IYER, R. N. (1971) Immunochemistry 8, 705-718.

13. Martineau, R. S, and Allen, P. Z. (1973) $\mathrm{Im}$ munochemistry 10, 829-838.

14. Lüderitz, O., Westphal, O., Staub, A. M., and Le Minor, L. (1960) Nature (London) 188, 556-558.

15. Iyer, R. N., AND Goldstein, I. J. (1973) Immunochemistry 10, 313-322.

16. Goldstein, I. J., Hammarström, S., and SundBLAD, G. (1975) Biochim. Biophys. Acta 405, $53-61$.

17. Hayes, C. E., and Goldstein, I. J. (1974) J. Biol. Chem. 249, 1904-1914.

18. Hodge, J. E., ANd Hofreiter, B. T. (1962) Methods Carbohyd. Chem. 1, 380-394.

19. Janatova, J., Fuller, J. K., and Hunter, M. J. (1968) J. Biol. Chem. 243, 3612-3622.

20. Rosen, H. (1957) Arch. Biochem. Biophys. 67, 10-15.
21. Reisfeld, R. A., Lewis, U. J., and Williams, D. E. (1962) Nature (London) 195, 281-283.

22. LAemmLI, U. K. (1970) Nature (London) 227, 680-685.

23. So, L. L., And Goldstein, I. J. (1967) J. Biol. Chem. 242, 1617-1622.

24. Kabat, E. A., ANd Meyer, M. M. (1961) in Experimental Immunochemistry, 2nd ed., pp. 22-96, C. C Thomas, Springfield, Ill.

25. Goldstein, I. J., ANd So, L. L. (1965) Arch. Biochem. Biophys, 111, 407-414.

26. Moore, S., ANd Link, K. P. (1940) J. Biol. Chem. 133, 293-311.

27. Julius, M. H., Simpson, E., ANd Herzenberg, L. A. (1973) Eur. J. Immunol. 3, 645-649

28. Hoare, D. G., and Koshland, D. E. (1967) $J$. Biol. Chem. 242, 2447-2453.

29. Brown, J. R. (1975) Fed. Proc. 34, 591.

30. So, L. L., And Golnstein, I. J. (1967) J. Immunol. 99, 158-163.

31. So, L. L., AND Goldstein, I. J. (1969) Carbohyd. Res. 10, 231-244.

32. Nicolson, G. L., Blaustein, J., and Etzler, M. E. (1974) Biochemistry 13, 196-204.

33. Reichert, C. F., Pan, P. M., Mathews, K. P., AND Goldstein, I. J. (1973) Nature New Biol. 242, 146-147.

34. Wang, J. L., McClain, D. A., and Edelman, G. M. (1975) Proc. Nat. Acad. Sci. USA 72, 1917-1921.

35. For a discussion thereof, see KАват, E. A. (1968) in Structural Concepts in Immunology and Immunochemistry, 1st ed., pp. 82-111, Holt, Rinehart and Winston, New York. 